\title{
HUMORISTIČAN PRIKAZ ŠKOLSKOG SUSTAVA U VRIJEME PANDEMIJE KORONAVIRUSA NA PRIMJERU VIZUALNO- VERBALNIH INTERNETSKIH ŽANROVA
}

\section{ŽELJKO PREDOJEVIĆ}

Katedra slavenskih filologija, Filozofski fakultet, Sveučilište Komenski u Bratislavi

Izvorni znanstveni rad Primljeno:22. 12. 2020. Prihvaćeno: 24. 2. 2021.

DOI: $10.15176 /$ vol58no106

UDK $373.55: 398.23$ 616-036.22COVID-19

U radu se analizira humorističan prikaz školskog sustava u vrijeme pandemije koronavirusa na primjeru vizualno-verbalnih internetskih žanrova (image macro memi i viralne fotografije) u kontekstu humora o aktualnostima (engl. topical humor), tj. u suodnosu sa žanrom vica o aktualnostima (engl. topical jokes). Nudi se njihova tematsko-motivska tipologija u tri skupine motivirana najčešćim prikazima koronavirusa u školskom sustavu. Riječ je o 1) provođenju epidemioloških mjera za suzbijanje širenja koronavirusa u školama, 2) organizaciji nastavnog procesa u vrijeme pandemije te 3) reakcijama nastavnog osoblja na upute i izjave čelnika u školskom sustavu vezane uz organizaciju nastave u vrijeme pandemije. Ukazuje se na povezanost analiziranih primjera s vijestima u medijima i na satiričan prikaz čelnika u školstvu. $U$ drugom se dijelu rada pokušava prikazati na koji se način postiže humorni učinak u vizualno-verbalnim internetskim žanrovima. Istraživanje je usmjereno na primjere objavljene na profilima društvenih mreža dviju aktivnih mrežnih stranica u sustavu obrazovanja - Nastavnici.org i Srednja.hr. Analizirani su primjeri objavljeni od početka pandemije koronavirusa u ožujku 2020. godine do kraja rujna iste godine.

Ključne riječi: humor o aktualnostima, vic, digitalni folklor, image macro, viralna fotografija, COVID-19, koronavirus, politički humor, društvene mreže, školski sustav

$U$ vrijeme pandemije novog koronavirusa iz sigurnosnih su razloga zatvorene školske ustanove, a ministarstva koja u okviru svog djelovanja imaju obrazovanje morala su brzo pronaći alternativni način izvođenja nastavnog procesa. Nastava je iz učionica preseljena 
na mrežu i televizijske programe. Školski sustav, također, nije bio spreman za radikalne promjene uvjetovane pandemijom koronavirusa. Odmah po uvođenju nastave na daljinu, na društvenim se mrežama pojavio velik broj primjera internetskih žanrova koji prikazuju učenike, nastavnike i druge dionike školskog sustava u humorističnim situacijama koje aludiraju na novi način (ne)funkcioniranja nastavnog procesa. $U$ ovom se radu analizira taj humorističan prikaz školskog sustava na primjeru vizualno-verbalnih internetskih žanrova (image macro internetski memi i viralne fotografije) u kontekstu humora o aktualnostima (engl. topical humor). Istraživanje je usmjereno na internetske žanrove objavljene na dva profila na društvenim mrežama, a riječ je o Nastavnici.org i Srednja.hr. Promatrat će se u okviru digitalnoga folklora (engl. weblore, Internet lore, netlore) kao vizualno-verbalne inačice viceva ${ }^{2}$ što nastaju kao reakcija na određeni aktualni društveni ili politički problem (engl. topical (cycle) jokes). Za njih je karakteristično da se javljaju ubrzo nakon što se dogodila situacija koja je potakla njihov ciklus, a prestaju biti aktualni kada takvom prestane biti i sama tema koja ih je potakla (usp. Dorst 1990: 181; Ellis 2001; Laineste 2012: 8; Marsh 2019: 218). lako su imanentni i usmenoj kulturi (usp. npr. Dundes 1989), od pojave interneta i brzine prijenosa informacija, ali i anonimnosti koju on jamči, tematski ciklusi viceva javljaju se učestalije (usp. Davies 2003: 30; Ellis 2001; ${ }^{3}$ Frank 2009: 106-107; Blank 2013: xvii). S obzirom na činjenicu da često nastaju kao reakcija na vijesti o kojima se izvještavalo u medijima, Russell Frank (2011: 7) takav tip internetskih žanrova naziva newslore. No, velik broj ih se odnosi na čelnike i institucije u školstvu, stoga se mogu interpretirati i u kontekstu političkog humora (usp. Young 2018). U Hrvatskoj su se, primjerice, takvi tematski ciklusi humornih internetskih žanrova pojavili u vrijeme predsjedničke kampanje i predsjedanja Kolinde Grabar Kitarović (usp. Jambrešić Kirin 2017), kao i u vrijeme skandala s bivšim hrvatskim premijerom Ivom Sanaderom (usp. Bebić i Volarević 2018).

\section{INTERNETSKI VIZUALNO-VERBALNI HUMORNI ŽANROVI KAO DIGITALNI FOLKLOR I NJIHOV ODNOS S KLASIČNIM FOLKLORNIM ŽANROVIMA}

U humorističnom prikazu školskog sustava u vrijeme pandemije koronavirusa analizirana su dva vizualno-verbalna internetska žanra koja nastaju kombinacijom fotografije ${ }^{4}$ i teksta, a riječ je o image macro internetskim memima ${ }^{5}$ (engl. image macro) i viralnim fotografi-

\footnotetext{
${ }^{1}$ Riječ profil u ovom radu odnosi se na korisnički profil na društvenim mrežama.

$2 U$ literaturi na engleskom jeziku uvijek se koristi riječ joke, koju je teško jednoznačno prevesti na hrvatski jezik, a mogućnosti prijevoda su šala, vic i dosjetka (usp. Marković 2018: 134-136).

${ }^{3}$ Vidi 4. poglavlje, stranice u radu nisu numerirane.

${ }^{4} \mathrm{Na}$ analiziranim se profilima pojavljuju i karikature i stripovi preuzeti s nekih drugih mrežnih stranica i profila s društvenih mreža, no oni se u ovome radu neće analizirati.

${ }^{5}$ Internetski memi su slike, videoisječci ili kratki tekstovi, tipično humoristične prirode, koji se šire internetom velikom brzinom, često uz male izmjene (https://en.oxforddictionaries.com/definition/meme (pristup 17. 9. 2020.)). Limor Shifman (2014: 11) ih definira kao: “a) skupinu digitalnih stavki koje dijele zajedničke
} 
jama ${ }^{6}$ (engl. virals, viral photos). Ono što im je zajedničko i zbog čega ih možemo smatrati digitalnim folklornim izričajima jest činjenica da ih ne potpisuje jedan autor. U njihovu stvaranju, širenju i recepciji važniju ulogu ima internetska zajednica nego pojedinac koji ih je prvi uredio ili oblikovao, kao što je to i u klasičnim folklornim izričajima (usp. Laineste i Voolaid 2016: 32). Te internetske zajednice ljudi (korisnika) sličnih interesa imaju i identitetsku ulogu (usp. Miltner 2014; Gal et al. 2016; Yus 2018). U njima se zamjećuje komunikacija i interakcija među korisnicima, tj. to da korisnici stvaraju, uređuju i prosljeđuju internetske žanrove (meme, viralne fotografije) za druge korisnike te zajednice, što se može povezati i s klasičnim folklornim praksama (usp. McNeill 2009: 84; Frank 2011: 9, de Seta 2019: 14).

U usmenoj kulturi poznati su ciklusi viceva istog tematskog predloška, poput, primjerice, onih o malom Perici (ili Ivici) i učiteljici. Strukturom su uglavnom tročlani (usp. Užarević 2012: 74), a upoznatiji recipijenti već unaprijed poznaju situacijski slijed stvaranja humornog učinka koji mogu očekivati kada im netko želi ispričati takav vic. Mali Perica odgovarajući na učiteljičino pitanje $u$ trećem, posljednjem dijelu vica, izgovara nešto što čini njegovu poentu (usp. Užarević 2012: 74) i izaziva humorni učinak. Primjeri:

(1) Upitala učiteljica Pericu:

- Kako se zove proces kada se narod pobuni?

Na to će Perica:

- Menstruacija!

- Kako menstruacija, valjda revolucija?!

A Perica odgovara:

- Pa isto neko krvoproliće!

(2) Pita učiteljica Pericu:

- Perice koga više slušaš, mamu ili tatu?

- Pa naravno Mamu!

- Što mamu? - pita učiteljica.

- Ona najviše priča!?

Sličan je postupak i u image macro memima. Upućeniji recipijent prema strukturi fotografskog predloška (engl. template) unaprijed prepoznaje slijed humorne situacije koju ta vizualno-verbalna šala treba zadovoljiti, a ono što se uvijek mijenja je (kon)tekst. Primjerice mem Finding Neverland ${ }^{8}$ strukturalno je podijeljen na tri dijela: pitanje - odgovor na postavljeno pitanje - poenta (vidi slikovni prilog 1).

\footnotetext{
karakteristike sadržaja, oblika i/ili stavova; b) koji su stvoreni sa sviješću jedni o drugima; i c) koji kruže, imitiraju se i/ili preoblikuju na internetu među brojnim korisnicima”. Najčešći oblik internetskih mema su image macro memi - memi u kojima je kombinirana fotografija s tekstom (usp. Davison 2012: 127).

${ }^{6}$ Viralne fotografije su internetski žanr koji također najčešće nastaje kao kombinacija fotografija s tekstom, no one nisu varijacije iste fotografije, tj. ne pojavljuju se u raznim inačicama na istu osnovu poput internetskih mema, već su jedinstveni primjeri koji su brzo postali iznimno uspješni (engl. viral) na društvenim mrežama i brzo se šire internetom (usp. Shifman 2014: 56).

7 https://www.najboljivicevi.com/kategorija/mali_perica-2-0.php (pristup 9. 10. 2020.).

${ }^{8} \mathrm{https}$ ///knowyourmeme.com/memes/finding-neverland (pristup 9. 10. 2020.).
} 

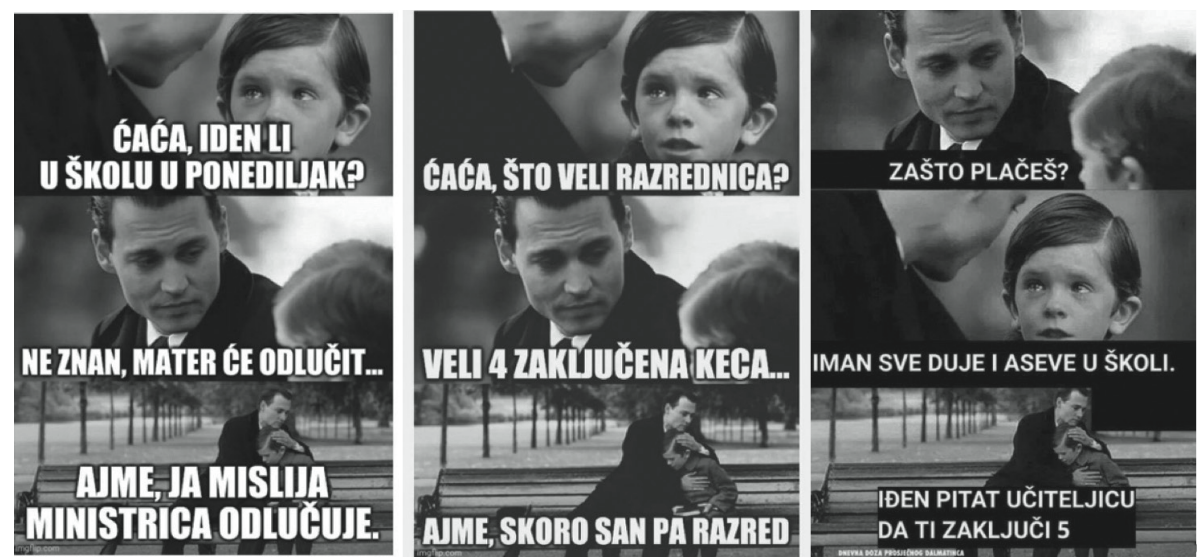

Slikovni prilog 1. Internetski mem Finding Neverland. Izvor: Nastavnici.org

Iz ovih je primjera razvidno da oba žanra slijede sličan strukturalni slijed stvaranja humorne situacije, stoga se može pretpostaviti da se humor u internetskim memima gradi po uzoru na "klasične" folklorne humorne žanrove, samo što je on prilagođen digitalnom načinu komuniciranja koji je na društvenim mrežama češće vizualan nego verbalan. ${ }^{9}$ Tekstualni (verbalni) internetski memi često u svojim izričajima imitiraju klasične folklorne žanrove (usp. Predojević 2019, 2021). U ovom slučaju, gdje je uz verbalnu naglašena i vizualna poruka, može se povući paralela s dvodijelnom ili trodijelnom strukturom vica (usp. Užarević 2012: 74; Marković 2019: 131), koja se u image macro memima oponaša i vizualno jer je fotografski predložak mema često i strukturom podijeljena na dva ili tri dijela.

Image macro memi su žanrovski oblik vizualno-verbalnog humora (usp. Dynel 2016) koji je toliko vizualan da se čak ni unutar obitelji ne prepričava, nego se među ukućanima dijeli digitalno (usp. Fiadotava 2020). No, unatoč toj činjenici, oni se često uspoređuju s klasičnim folklornim žanrovima poput vica, šale ili dosjetke (engl. joke) jer s njima imaju mnogo dodirnih točaka (usp. Dynel 2016; Laineste i Voolaid 2016; Szerszunowicz 2018; Vargha 2018; Marković 2019: 135). Takav pristup usporedbe internetskih žanrova s klasičnima nije svojstven samo za internetski mem nego i za druge internetske žanrove (usp. Baran 2012; Oring 2012; Lainsete 2016). Na koncu, ponekad je već samo upotreba poznatih žanrova u novom kontekstu dovoljna za stvaranje humora (usp. Laineste 2016: 21).

Jednako kao što se može povezati internetski mem i vic, vic se može povezivati i sa žanrom viralne fotografije. Viralne fotografije i image macro memi nastaju na isti način uz pomoć programa za uređivanje fotografija. Jedina je razlika to što su viralne fotografije samostalne jedinice vernakularne kulture digitalnog doba, tj. ne nastaju kao razne inačice jednog fotografskog predloška, kao što je to slučaj kod image macro mema. Sam pojam

${ }^{9}$ Tomu svjedoči niz društvenih mreža koje su fokusirane uglavnom na vizualno poput Instagrama, Pinteresta, Tumblra i sl. 
viralne fotografije nastao je kako bi se učinila distinkcija od žanra internetskog mema s kojim su se često brkale zbog iste tehnike uređivanja i istog virtualnog prostora u kojem se pojavljuju, a uglavnom je riječ o društvenim mrežama (usp. Shifman 2014: 55-63; Dynel 2016: 662). Premda je razlika image macro mema i viralnih fotografija kao internetskih žanrova razvidna, ona je zanemariva kada ih uspoređujemo s klasičnim folklornim žanrovima. Oba se žanra mogu promatrati kao virtualni surogati klasičnih humornih folklornih žanrova, u ovom slučaju vica.

\section{TEMATSKO-MOTIVSKA ANALIZA HUMORNOG DISKURSA VIZUALNO-VERBALNIH INTERNETSKIH ŽANROVA NA PRIMJERU PROFILA NASTAVNICI.ORG I SREDNJA.HR NA DRUŠTVENIM MREŽAMA}

Nastavno na prijašnje istraživanje o humorističnom prikazu pandemije koronavirusa na primjeru tekstualnih (verbalnih) internetskih mema u kontekstu vica katastrofe (Predojević 2021), u ovom će se radu analizirati humorni diskurs vizualno-verbalnih internetskih žanrova koji se pojavljuju na dva profila na društvenim mrežama čiji se tematski okvir odnosi na školski sustav u vrijeme pandemije koronavirusa. Provest će se tematsko-motivska analiza prikaza pandemije na primjeru školskog sustava, a kroz nju će se na odabranim primjerima ukazati na njihovu usku povezanost s vijestima o kojima su izvještavali mediji.

Mrežna stranica Nastavnici.org ${ }^{10}$ uglavnom okuplja dionike izvedbenog nastavnog procesa, odnosno učitelje, nastavnike, profesore, stručne suradnike i ravnatelje. Na društvenoj mreži Facebook nalazi se i njezin privatni profil" na kojem oni komentiraju i objavljuju aktualnosti koje se tiču školskog sustava. Mrežna stranica Srednja.hr je "news portal za studente i srednjoškolce u Hrvatskoj”." Na društvenoj mreži Instagram nalazi se njezin profil $^{13}$ na kojem se objavljuju samo internetski žanrovi koji će se u ovom radu i analizirati. $\mathrm{Na}$ dan 30. rujna 2020. godine, u vrijeme pisanja ovog teksta, Facebook skupina Nastavnici.org broji 18216 članova, a instagramski profil Srednja.hr više od 39 tisuća pratitelja. Navedeni su profili odabrani jer su njima pokriveni svi dionici nastavnog procesa - od učenika, koji su zastupljeniji na profilu Srednja.hr, do nastavničkog osoblja, koje je aktivnije na profilu Nastavnici.org.

Prije analize internetskih žanrova ukratko će se opisati kako je funkcionirao školski sustav u Republici Hrvatskoj u spomenutom razdoblju. Od 16. ožujka 2020. godine zatvorene su sve školske ustanove i započela je nastava na daljinu. Najmlađi učenici razredne nastave

\footnotetext{
${ }^{10}$ http://nastavnici.org (pristup 29. 9. 2020.).

${ }^{11}$ Privatni profil je onaj koji nije javno dostupan, čije objave mogu vidjeti samo članovi te skupine (https:// www.facebook.com/groups/nastavnici.org (pristup 29. 9. 2020.)).

${ }^{12}$ https://www.srednja.hr/ (pristup 29. 9. 2020.).

${ }^{13}$ https://www.instagram.com/srednja_hr/ (pristup 29. 9. 2020.).
} 
pratili su Školu na trećem, ${ }^{14}$ tj. TV nastavu koja se emitirala u prijepodnevnim satima na Trećem programu Hrvatske radiotelevizije, uz konzultacije na daljinu sa svojim učiteljima. Učenici predmetne nastave, srednjoškolci i studenti nastavu su pratili na mreži putem raznih aplikacija. Od 11. svibnja u školske su se ustanove trebali vratiti učenici razredne nastave, no zbog nejasnog načina povratka učenika u škole o kojem su roditelji sami trebali odlučivati, ${ }^{15}$ to se nije dogodilo u svim školama, nego samo u onima gdje su to dopuštale epidemiološke okolnosti. ${ }^{16}$ No, od 25. svibnja započela je obvezna redovna nastava za učenike razredne nastave, ${ }^{17}$ a ostali su učenici i dalje pratili nastavu na mreži do kraja nastavne godine u školskoj godini 2019./2020. Nova nastavna godina, s novim ministrom obrazovanja, ${ }^{18}$ započela je 7. rujna i organizirana je u tri modela ${ }^{19}$ izvođenja nastave, ovisno o epidemiološkoj situaciji u samoj školi, mjestu i županiji. S obzirom na to da su modeli po kojima se trebala izvoditi nastava u novoj školskoj godini objavljeni tek koncem kolovoza, prethodio im je niz reakcija internetskih korisnika na temu realizacije nove školske godine.

Analizirat će se 126 primjera internetskih žanrova (65 viralnih fotografija i 61 image macro mem) objavljenih od početka pandemije koronavirusa u ožujku 2020. godine do konca rujna iste godine. Analizirani se primjeri mogu podijeliti u tri tematsko-motivske skupine motivirane načinom prikaza pandemije $u$ školskom sustavu: 1) primjeri koji prikazuju reakcije na provođenje epidemioloških mjera za suzbijanje širenja koronavirusa u školama, 2) primjeri koji prikazuju reakcije na organizaciju nastave u vrijeme pandemije i 3) primjeri koji prikazuju reakcije nastavnog osoblja na upute i izjave čelnika i institucija u školstvu vezane uz organizaciju nastave u vrijeme pandemije.

\section{REAKCIJE NA PROVOĐENJE EPIDEMIOLOŠKIH MJERA U ŠKOLAMA}

U prvoj tematsko-motivskoj skupini riječ je o 30 primjera kojima se ukazuje na novonastale životne situacije uvjetovane pandemijom koronavirusa u školskom sustavu, tj. na epidemiološke mjere koje su krizni stožeri uveli radi suzbijanja širenja virusa. Uglavnom je riječ o nošenju zaštitnih maski, preporučenoj socijalnoj distanci, čestim dezinfekcijama prostora,

${ }^{14}$ https://i-nastava.gov.hr/vijesti/skola-na-trecem/67 (pristup 22. 9. 2020.) Škola na trećem se i reprizirala u popodnevnim satima, a bila je dostupna učenicima i na internetu tako da nisu morali pratiti samo nastavu $u$ realnom vremenu na televiziji.

15 https://hr.nlinfo.com/vijesti/a502631-blazenka-divjak-djecu-nece-nitko-tjerati-u-skolu-roditelji-ce-odluciti-o-tome/ (pristup 22. 9. 2020.).

${ }_{16}$ Škole su provele ankete u kojima su se roditelji trebali izjasniti o povratku učenika u škole te se nastava trebala organizirati prema rezultatima tih anketa i sukladno epidemiološkoj situaciji.

${ }_{17}^{17}$ Uz razrednu nastavu, otvorene su i predškolske ustanove, a u škole su se vratili i posebni razredni odjeli i djeca s teškoćama koja imaju pomoćnika u nastavi.

${ }^{18} \mathrm{U}$ međuvremenu su u Republici Hrvatskoj organizirani parlamentarni izbori te obrazovanje dobiva novoga ministra Radovana Fuchsa.

${ }^{19}$ Model A odnosio se na redovnu nastavu u školskim ustanovama pod strogim epidemiološkim mjerama, Model B odnosio se na kombiniranu redovnu nastavu i nastavu na daljinu, a Model C odnosio se na nastavu na daljinu. 
mjerenju tjelesne temperature pri ulasku u školu, kompliciranim pripremama rasporeda sati zbog poželjnog što rjeđeg susretanja na školskim hodnicima i sl. Pridržavanje zadanih mjera prikazano je aludiranjem na određenu epidemiološku mjeru postavljenju u kontekst vezan uz dionike nastavnog procesa. U ponekim se primjerima indirektno kritiziraju neke od u medijima najavljivanih mjera (usp. Cindrić 2020): primjerice, propituje se koliko bi bilo uspješno nošenje zaštitnih maski za najmlađe učenike razredne nastave i koliko je učinkovita socijalna distanca u učionici ako je se učenici izvan nje ne pridržavaju. Bitno je napomenuti da neke od humoristično prikazanih mjera nisu ni uvedene kao obvezne, ali se upravo pretjerivanjem i postiže humorna situacija.

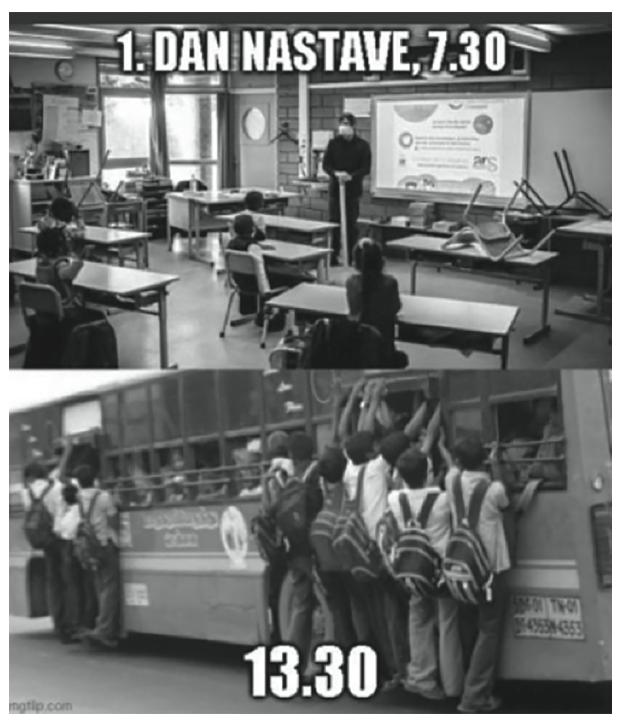

Ali ovo nije maska koju si jutros ponio u školu...

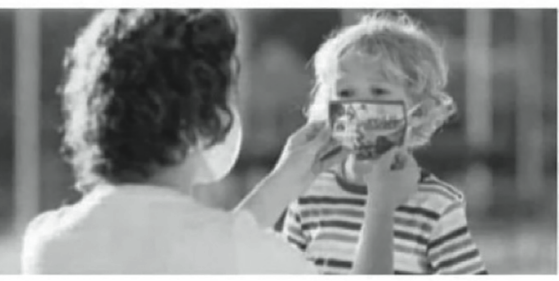

$\mathrm{Ne}$, ja sam se mijenjao s Markom, a Marko se mijenjao s Leonom..

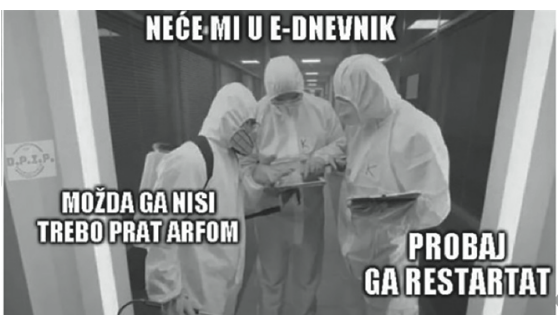

Slikovni prilog 2. Humorističan prikaz provođenja mjera u školskom sustavu (izabrani primjeri). Izvor: Nastavnici.org i Srednja.hr instagramski profil

\section{REAKCIJE NA ORGANIZACIJU NASTAVE U VRIJEME PANDEMIJE}

Druga tematsko-motivska skupina odnosi se na organizaciju nastave u vrijeme pandemije i broji najviše primjera (71). Najviše je reakcija izazvala nastavu na daljinu, što ne čudi jer se takav oblik nastave prvi put pojavio kao obvezan za sve dionike nastavnog procesa (usp. Vrbanus 2020), a najčešće je šaljivo prikazivana TV nastava. lako je bila obvezna samo za učenike razredne nastave, korisnici su je šaljivo prikazali na svim razinama obrazovanja. Uređen je niz primjera koji prikazuju učenike ili studente koji prate određenu televizijsku emisiju kojom se šaljivo aludira na određeni nastavni predmet ili na školsko usmjerenje - primjerice nastava za studente pravnih fakulteta prikazana je kao praćenje televizijske emisije Sudnica. 


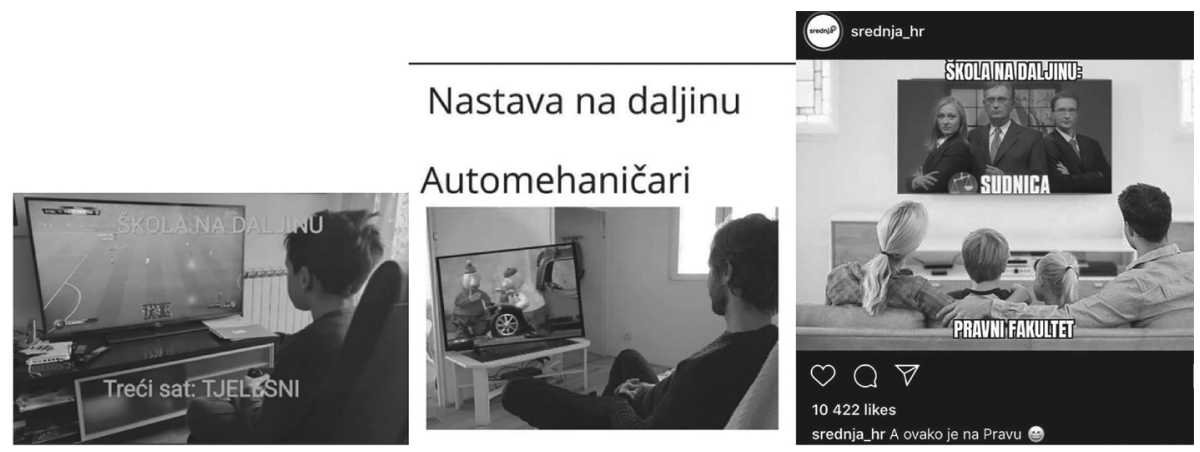

Slikovni prilog 3. Humorističan prikaz TV nastave (izabrani primjeri). Izvor: Srednja.hr

Osim aludiranjem na određeni nastavni predmet ili školsko usmjerenje, TV nastava prikazana je humoristično i aludiranjem na neke situacije i aktivnosti povezane s nastavnim procesom (školski redar, markiranje s nastave i sl.).
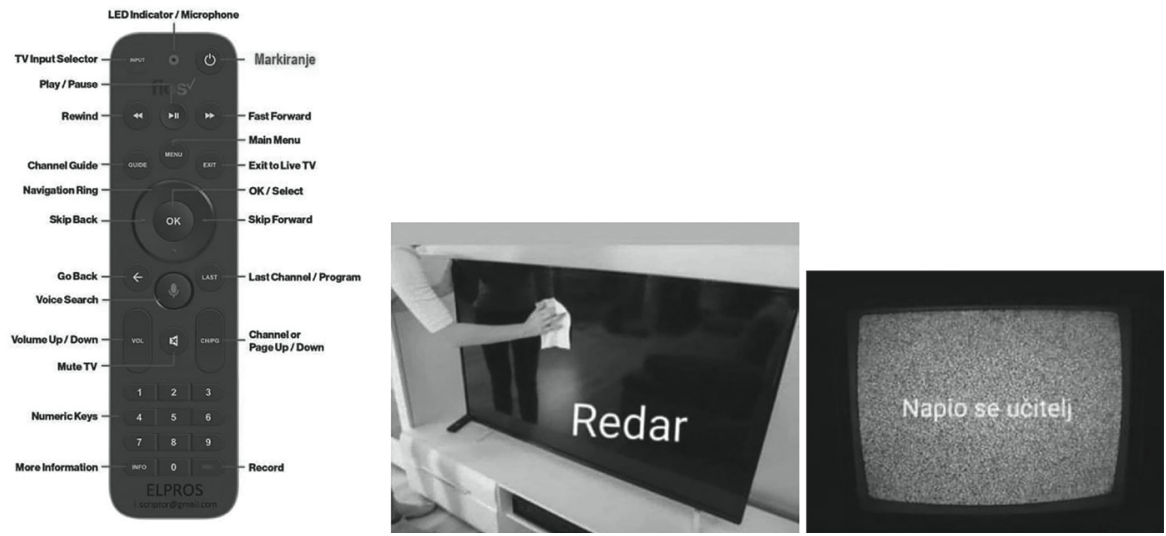

Slikovni prilog 4. Humorističan prikaz TV nastave (izabrani primjeri). Izvor: Srednja.hr i Nastavnici.org

Prikaz nastave na mreži također slijedi tematsku okosnicu onoga s televizijskim programom te prikazuje dionike nastavnog procesa u novonastalim situacijama ili radnjama povezanim s njim. Primjerice, prikazane su učenice za vrijeme velikoga odmora prije pandemije i u vrijeme nastave na mreži, zatim Google Prevoditelj kao mrežni oblik nastave engleskoga jezika. Ponavlja se i tema bježanja, tj. markiranja iz škole koja je ovdje prikazana isključivanjem kamere i zvučnika na računalnim aplikacijama na kojima se izvodila nastava. 


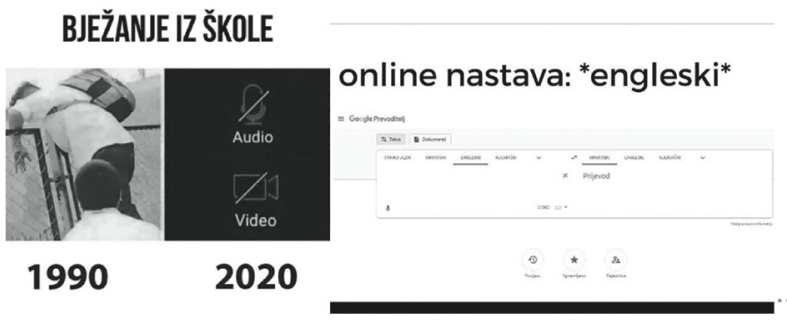
cure za vrijeme velikog odmora u 2019. vs cure za vrijeme velikog odmora u 2020.

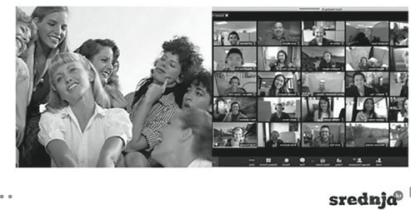

Slikovni prilog 5. Humorističan prikaz nastave na mreži (izabrani primjeri). Izvor: Srednja.hr i Nastavnici.org

Kao česta reakcija na nastavu na mreži ističe se tema "lajkanja" nastavničkih uputa. Naime, savjetovalo se da učenici ne komentiraju nastavničke objave, nego da im daju do znanja da su ih vidjeli tako što ih označe s opcijom "sviđa mi se", poznatijoj u engleskoj inačici "like". Primjerima se ukazuje na to da nastavnici i učenici taj način komuniciranja nisu dobro prihvatili.

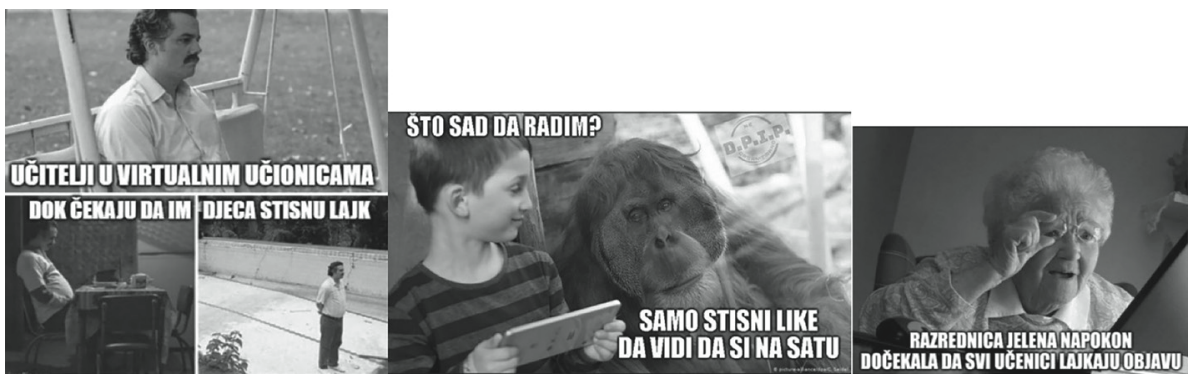

Slikovni prilog 6. Humorističan prikaz "lajkanja" nastavničkih objava (izabrani primjeri). Izvor: Srednja.hr i Nastavnici.org

Česti su i prikazi stresnosti izvođenja nastave na daljinu kako za posredne tako i za neposredne dionike nastavnog procesa - od učenika preko nastavnika do roditelja. Oni najčešće prikazuju učenike ili mlade nastavnike i nastavnice kao osobe treće životne dobi s ironičnim verbalnim porukama koje ukazuju na stresnost situacije (vidi i slikovni prilog 16).
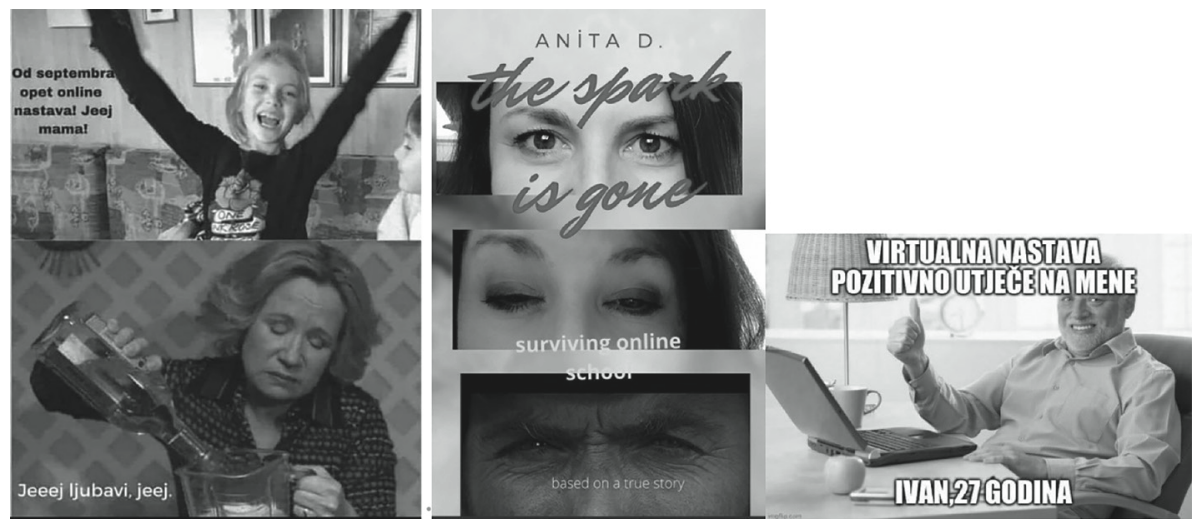

Slikovni prilog 7. Izabrani primjeri koji ukazuju na stresnost situacije. Izvor: Nastavnici.org 
U ovoj je skupini potrebno istaknuti i druge teme koje su se pojavljivale, primjerice problemi pri organizaciji mature, velika količina domaćih zadaća i, općenito, zabrinutost za kvalitetu nastave na daljinu, posebice za ona usmjerenja za koja je potrebna školska praksa ili neki oblik praktičnih vježbi, koje se u vrijeme nastave na daljinu nisu mogle izvoditi.

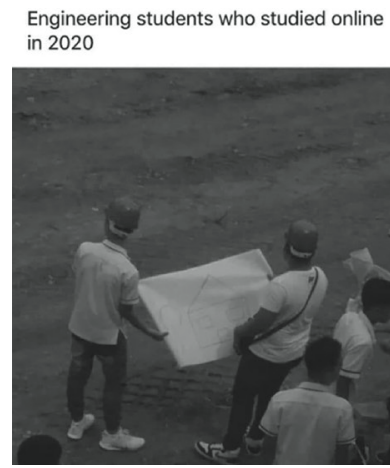

When you complete your engineering from online classes

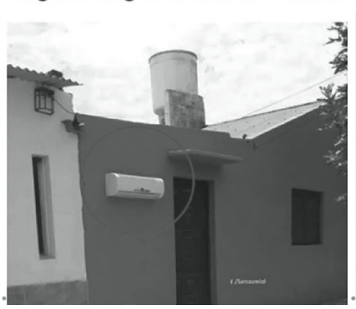

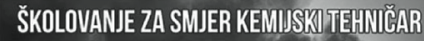

Slikovni prilog 8. Primjeri koji ukazuju na zabrinutost zbog kvalitete nastave na daljinu. Izvor: Nastavnici.org

\section{REAKCIJE NASTAVNOG OSOBLJA NA UPUTE I IZJAVE ČELNIKA I INSTITUCIJA U ŠKOLSTVU}

Trećom tematsko-motivskom skupinom, koja broji 25 primjera, ukazuje se na reakcije nastavnog osoblja na izjave i upute čelnika i institucija u školstvu, stoga se ona može analizirati u kontekstu političkog humora u sklopu kojeg satira zauzima važnu ulogu (usp. Young 2018). Humornim internetskim žanrovima imanentan je satiričan prikaz političkih aktera (usp. Jambrešić Kirin 2017; Ross i Rivers 2017), a u ovom su slučaju posebice komentirane odluke tadašnje ministrice znanosti i obrazovanja Blaženke Divjak. S obzirom na to da je početkom ožujka ministrica najavljivala mogućnost mrežne nastave ${ }^{20}$ koja se dotad nikada nije izvodila, satirično je prikazana kao lik iz poznate dječje televizijske serije Djevojčica iz budućnosti ili kao superjunakinja koja će pobijediti koronavirus. U nastavničkoj skupini Nastavnici.org njezine su odluke bile česta tema, stoga se ministrica javlja u više primjera kao glavni akter. Ti humoristični prikazi ministrice zapravo predstavljaju kritiku njezinih odluka, što je imanentno humoru na internetu (usp. Vásquez 2019: 31).

20 https://vijesti.hrt.hr/hrvatska/divjak-ako-se-aktivira-najgori-scenarij-skole-ce-nastavu-voditi-online-707620 (pristup 23. 9. 2020.). 


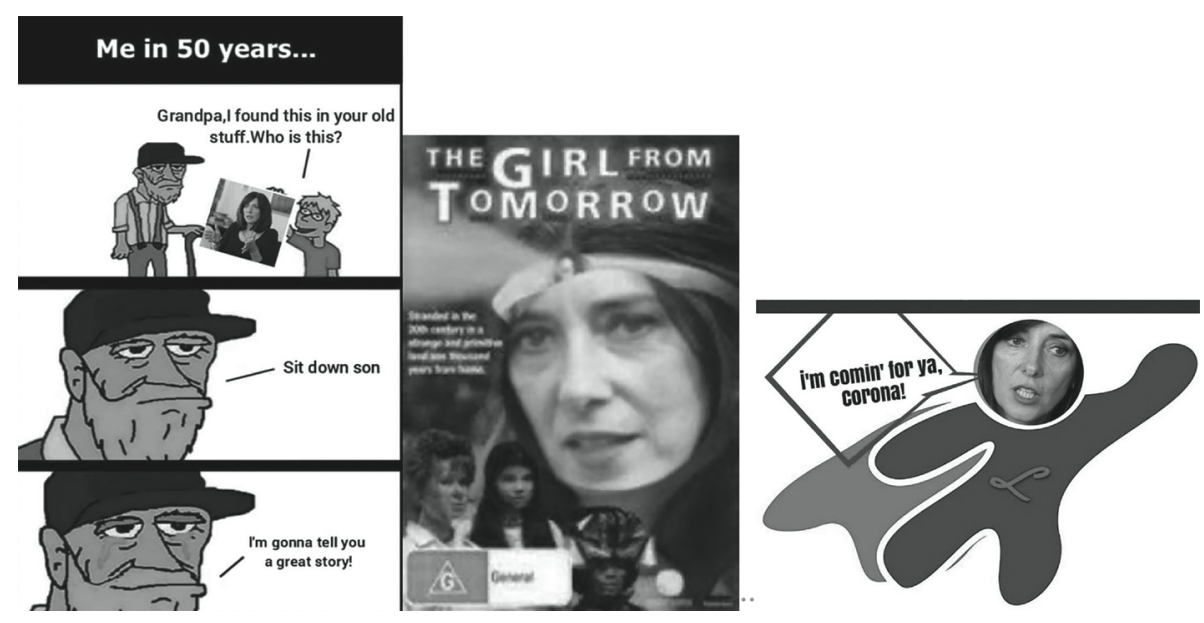

Slikovni prilog 9. Prikaz ministrice Blaženke Divjak u internetskim žanrovima (izabrani primjeri). Izvor: Nastavnici.org

Osim u navedenim primjerima, ministrica se kao akter javlja u njih još nekoliko kojima se reagira na njezinu izjavu u medijima ${ }^{21}$ da će o povratku učenika u škole odlučivati roditelji, a ne sustav.
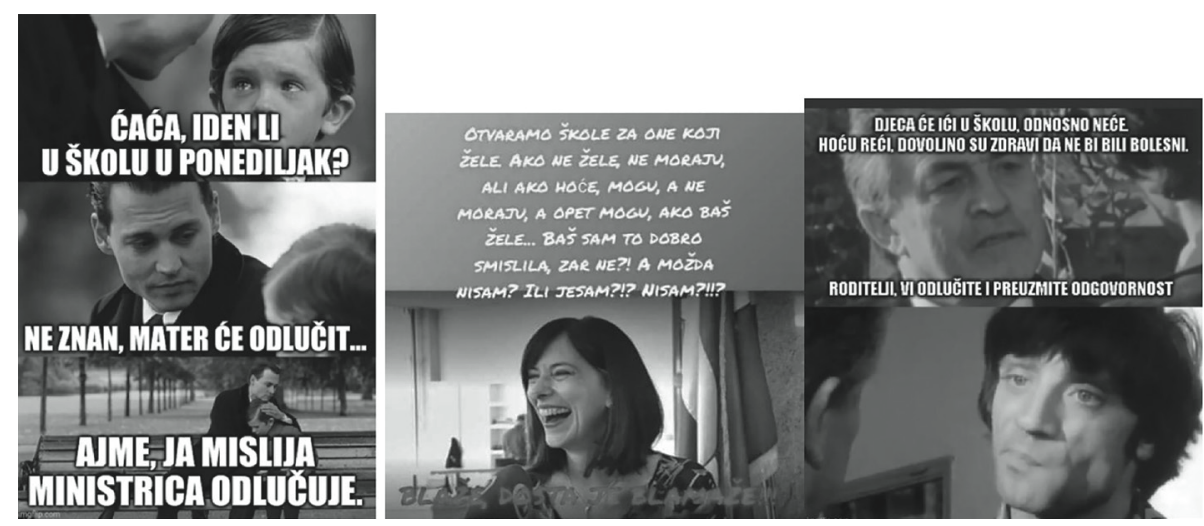

Slikovni prilog 10. Prikaz reakcija na izjavu ministrice Blaženke Divjak . Izvor: Nastavnici.org

Šaljivo su prikazivane i reakcije na brojne i dugačke upute Ministarstva znanosti i obrazovanja o organizaciji nastavnog procesa u vrijeme pandemije.

21 https://hr.n1info.com/vijesti/a502631-blazenka-divjak-djecu-nece-nitko-tjerati-u-skolu-roditelji-ce-odluciti-o-tome/ (pristup 22. 9. 2020.). 


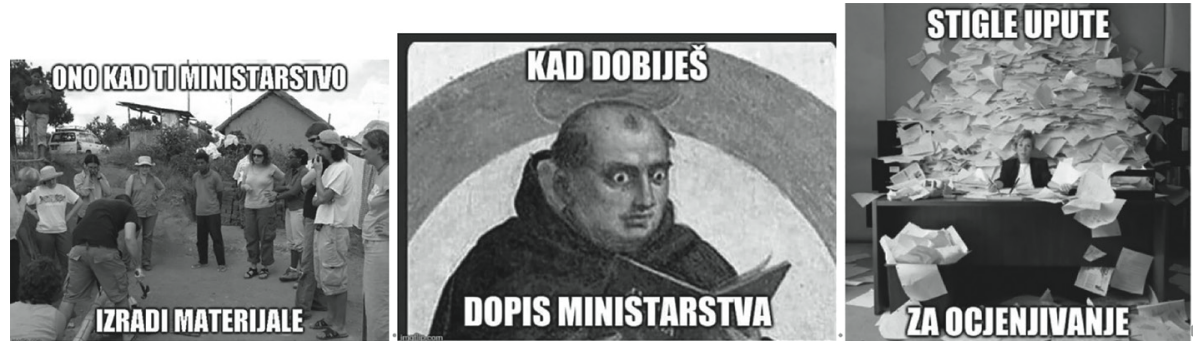

Slikovni prilog 11. Humorističan prikaz Ministarstva znanosti i obrazovanja. Izvor: Nastavnici.org

Posebice se ističe odluka Ministarstva da učenici zbog otežanih uvjeta rada neće ponavljati razred s više od dvije negativne ocjene kao što je to bilo do pandemije koronavirusa (usp. Kršul 2020).

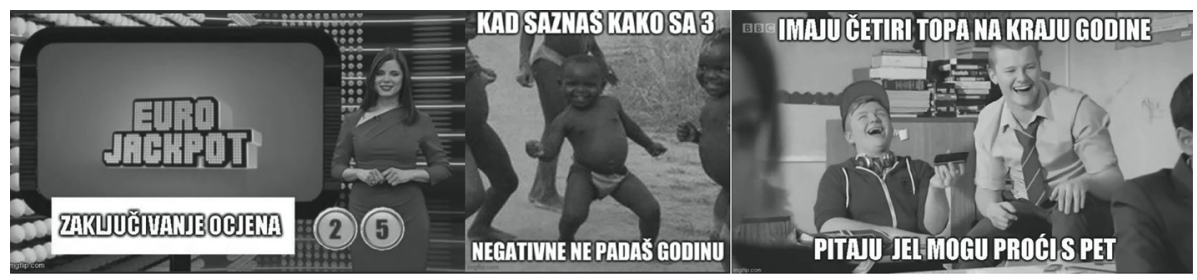

Slikovni prilog 12. Prikaz reakcija na odluku Ministarstva znanosti i obrazovanja o negativnim ocjenama. Izvor: Nastavnici.org i Srednja.hr

Ističe se i vijest o tzv. balončićima ${ }^{22}$ kojima se namjeravalo spriječiti miješanje učenika iz različitih razrednih odjeljenja.

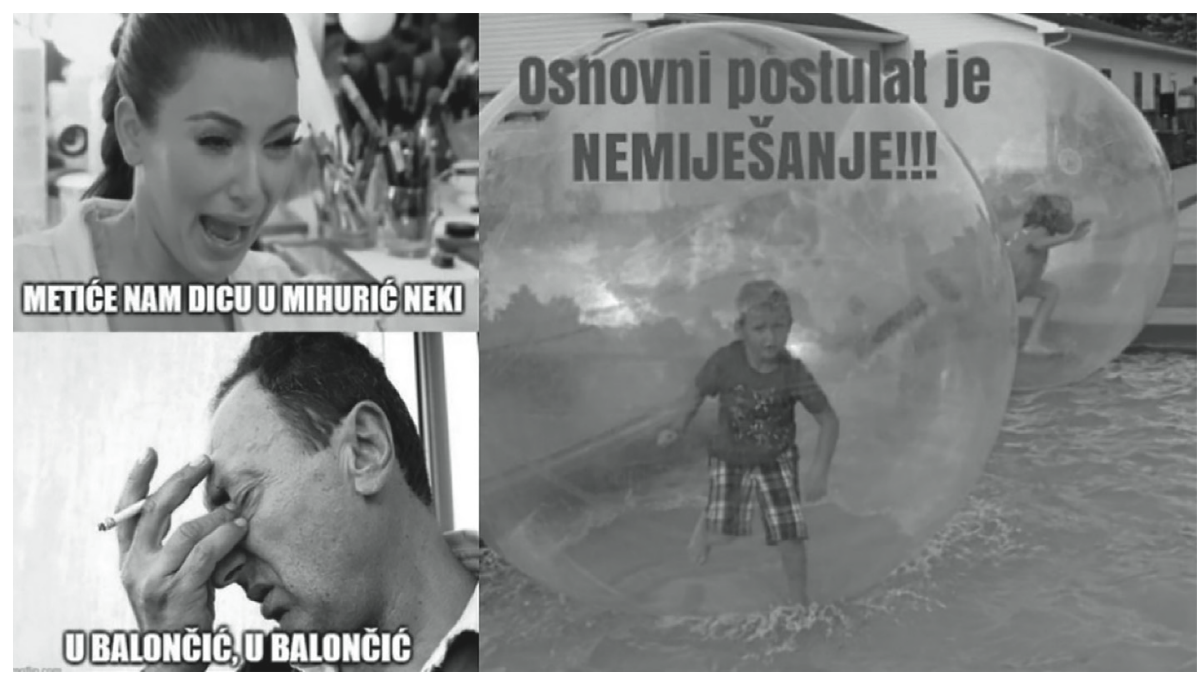

Slikovni prilog 13. Humorističan prikaz modela "balončića". Izvor: Nastavnici.org

22 https://net.hr/danas/hrvatska/procurili-detalji-pocetka-skolske-godine-nastava-za-prva-cetiri-razreda-odvijat-ce-se-po-sistemu-baloncic-ili-mjehuric/ (pristup 4. 10. 2020.). 


\section{ANALIZA HUMORNOG DISKURSA INTERNETSKIH ŽANROVA}

Iz tematsko-motivske analize humornog diskursa razvidno je da on nastaje kao reakcija dionika nastavnog procesa na novonastale situacije u vrijeme pandemije koji ukazuju na emski pogled na situaciju (vidi slikovne priloge 6, 7 i 11), ali i da je velik broj primjera nastao kao reakcija na vijesti u medijima (vidi slikovne priloge 2, 3, 10 i 13). Naime, humoru o aktualnostima imanentno je šaljivo komentiranje ili prikazivanje vijesti (usp. Frank 2011; Highfield 2015). Internetski žanrovi nastali kao reakcija na vijesti u medijima ukazuju i na aktualne probleme $u$ održavanju nastavnog procesa $u$ vrijeme pandemije te služe kao poticaj za konstruktivnu raspravu i formiranje stavova nastavničkog osoblja. Satiričnim se prikazima kritiziraju izjave i odluke institucija i čelnika u školstvu i jasno se ukazuje na njihovu diskutabilnost i na nezadovoljstvo nastavničkog osoblja tim odlukama (vidi slikovne priloge 9,10 i 11). Učinak humora u tim internetskim zajednicama može se promatrati dvojako - kao pozitivan i kao negativan. Budući da humor ima važnu ulogu u stvaranju grupa solidarnosti i identiteta u računalno posredovanoj komunikaciji (usp. Baym 2004; Vásquez 2019: 30), može se zaključiti da humorističan prikaz školskog sustava u vrijeme pandemije koronavirusa približava dionike nastavnoga procesa, tj. nastavnike okupljene na profilu Nastavnici.org i učenike na profilu Srednja.hr. Interakcija internetskih korisnika pri stvaranju, dijeljenju i komentiranju humornih internetskih žanrova utječe na formiranje kolektivnih identiteta unutar internetskih zajednica i stvara solidarnost među njima te im pomaže da zajednički prebrode koronakrizu. Humor u vrijeme pandemije važan je i za mentalno zdravlje i predstavlja obrambeni mehanizam pomoću kojeg se ljudi suočavaju sa samom situacijom. Međutim, upozorava se da takav tip humora izaziva i negativne reakcije u recipijenata, posebice onih koji pripadaju ugroženim skupinama (usp. Thelwall i Thelwall 2020; Bischetti et al. 2020). S obzirom na činjenicu da je ovaj tematski ciklus humora uvjetovan pandemijom, tj. prirodnom katastrofom i načinom na koji je ona predstavljena u medijima, može se analizirati i u kontekstu humora katastrofe (usp. Oring 1987; Davies 2003; Predojević 2021), koji prema mišljenju nekih istraživača također predstavlja kolektivnu mentalnu higijenu i obrambeni mehanizam (usp. Blank 2013: 23; Dundes 1987), dok drugi smatraju da takav humor nastaje samo radi zabave (Davies 2003: 33). Negativni učinci humorističnog prikaza školskog sustava u vrijeme pandemije odnose se na isticanje čelnika i institucija u školstvu uglavnom u lošem svjetlu. lako se humorom na internetu može prikrivati i javno vrijeđanje (usp. Suryawanshi et al. 2020), u ovom se slučaju najčešće samo kritiziraju odluke i izjave čelnika u školstvu. No kritika je na internetu često eksplicitnija, što se može pripisati činjenici da se internetski korisnici ne moraju suočiti s direktnom reakcijom zajednice (Vásquez 2019: 31; Blank 2013: xvii).

Kao što je bilo i za očekivati, profil Srednja.hr tematski je usmjeren na učenike, a Nastavnici.org na nastavno osoblje. Oba profila na sličan humorističan način ukazuju na novonastale situacije u školskom sustavu uvjetovane pandemijom, ali kritika čelnika i institucija u obrazovanju zastupljenija je na profilu Nastavnici.org, što je također bilo za očekivati jer se na njemu okupljaju dionici izvedbenog nastavnog procesa. No, na profilu 
Srednja.hr uočava se kritika upućena nastavnom osoblju koja se tiče izvedbenog nastavnog procesa i prevelike količine zadaća. Na oba se profila u podjednakoj mjeri javljaju oba internetska žanra, no razlika se uočava u temama koje internetski žanrovi prikazuju. I na nastavničkom i na učeničkom profilu viralnim fotografijama češće se prikazuje lokalna specifična situacija, a globalni problemi školskog sustava u vrijeme pandemije češće su prikazani žanrom image macro mema. Viralnim su se fotografijama vizualno uspješnije mogle prikazati lokalne novonastale okolnosti, tj. njima se konkretnije demonstrira lokalna specifična situacija (vidi slikovne priloge 3 i 9). Što se tiče žanra image macro mema, zamjećuje se da se najčešće pojavljuju globalno poznati memi koji su zabilježeni na mrežnoj stranici Know Your Meme, ${ }^{23}$ njihovoj neslužbenoj bazi podataka. Treba napomenuti da se primjeri objavljeni na jednom profilu ne pojavljuju na drugom, te da nije zabilježen ni jedan isti fotografski predložak mema koji bi prikazivao situaciju iz perspektive učenika i nastavnika. Isti se memi, ali s drukčijim verbalnim porukama, pojavljuju samo unutar istog profila. Primjerice, mem Finding Neverland pojavljuje se na profilu Nastavnici.org u osam inačica (vidi slikovne priloge 1 i 15), ali ni jednom na profilu Srednja.hr. Činjenica da se na analiziranim profilima ne javljaju isti primjeri dobro ukazuje i na identitetsku ulogu internetskih žanrova (usp. Miltner 2014; Gal et al. 2016; Yus 2018), tj. primjeri objavljeni na njima prilagođeni su kolektivnom identitetu internetske zajednice kojoj su upućeni, a za pretpostaviti je da će oni biti različiti među učenicima i nastavnicima. Nadalje, u većini je primjera verbalni dio napisan na hrvatskom jeziku, no pojavljuje se i engleski jezik, koji je lingua franca internetskih žanrova (usp. Laineste i Voolaid 2016: 27; Szerszunowicz 2018: 4). Primjeri koji su napisani na hrvatskom jeziku najčešće ukazuju na lokalnu specifičnu situaciju (primjerice slikovni prilog 13), iako to nije pravilo, pa su tako primjeri koji tematiziraju ministricu Divjak napisani i na engleskom jeziku (vidi slikovni prilog 9). Primjeri na engleskom jeziku uglavnom prikazuju globalne probleme školskog sustava u vrijeme pandemije i poticaj su za nastanak lokalnih (vidi slikovne priloge 8 i 15), a kada su adaptirani na hrvatski jezik ukazuju na lokalnu situaciju (vidi slikovni prilog 6). S obzirom na specifičnost situacije, tj. da se prvi put u povijesti nastava premjestila iz školskih učionica i studentskih dvorana na televizijske programe i mrežu, žanr koji dominira u prikazivanju krize školskog sustava u vrijeme pandemije je viralna fotografija. Njome su se vizualno uspješnije mogle prikazati novonastale situacije nego memima koji imaju unaprijed zadani fotografski predložak. lako vizualni humorni diskurs viralnih fotografija često tematski slijedi onaj koji se pojavljuje i u memima, ${ }^{24}$ većina ih je nastala kao direktniji prikaz nastave na daljinu (vidi slikovne priloge 2, 3, 4 i 5).

\footnotetext{
${ }^{23}$ https://knowyourmeme.com (pristup 3. 10. 2020.).

${ }^{24}$ Primjerice one koje ukazuju na stresnost situacije prikazujući mlade osobe kao osobe treće životne dobi (vidi slikovne priloge 7 i 16).
} 


\section{HUMORNI UČINAK U VIZUALNO-VERBALNIM INTERNETSKIM ŽANROVIMA}

U studijama koje analiziraju humor u vizualno-verbalnim folklornim izričajima napominje se da humorni učinak proizlazi iz određenog tipa nepodudarnosti ili inkongruentnosti ${ }^{25}$ koja se može prepoznati na više razina (usp. Tomašić 2018: 67). O sličnom se stvaranju humorna učinka govori i u studijama koje su usmjerene na vizualno-verbalne internetske žanrove gdje do humorna učinka dolazi humornim sudarom (engl. humorous clash) (usp. Kuipers 2002, 2005), kontradiktornošću ili nespojivošću elemenata (usp. Baran 2012) ili razrješenjem inkongruentnosti (engl. incongruity-resolution) koja se ostvaruje u različitim kombinacijama vizualnih i verbalnih elemenata (usp. Dynel 2016; Yus 2020). Uz navedeno, u internetskim vizualno-verbalnim žanrovima koji se odnose na određenu aktualnu situaciju (engl. topical jokes) važnu ulogu u stvaranju humorna učinka ima i kontekst, posebice ako je situacija na koju se odnose tematski specifična i prilagođena ciljanoj publici (usp. Laineste 2016: 19). Primjerice, u nekim je od analiziranih primjera u ovom radu humorni učinak bez konteksta upitan (vidi primjerice slikovne priloge 6 i 9). Kontekst im osigurava virtualni prostor na kojem su objavljeni ili podijeljeni, a riječ je o profilima na društvenim mrežama tematski usmjerenima na školstvo.

\section{-:Dobar dan doktoreee.. ?! $\sim$ Koji doktor, ja sam učiteljica!!}

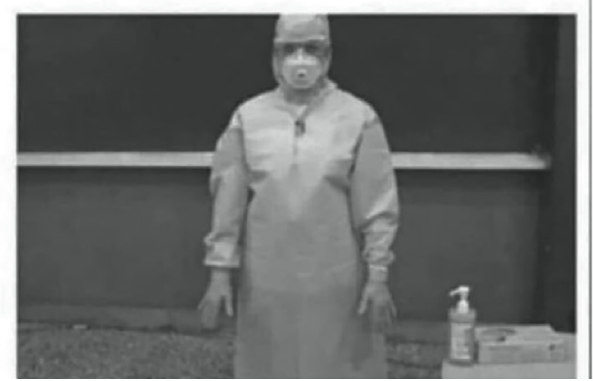

\section{MZO: "online nastava dobro funkcionira" online nastava:}

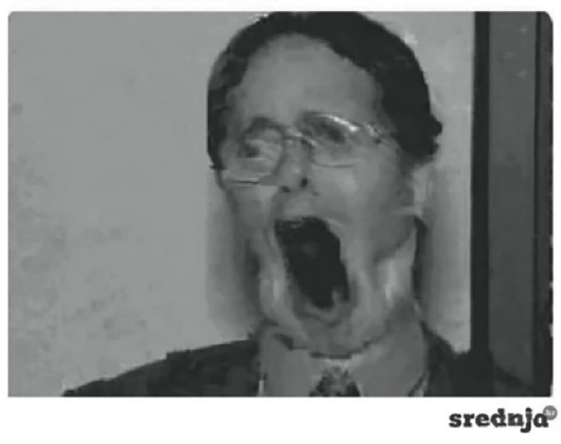

Slikovni prilog 14. Razrješenje inkongruentnosti u kombinaciji vizualnog i verbalnog. Izvor: Nastavnici.org i Srednja.hr

${ }^{25}$ Kada se govori o teorijama humora, teorija inkongruentnosti (engl. incongruity theory) često se ističe kao jedna od važnijih. Javlja se u 18. stoljeću i veže se uz imena poput Hutchesona, Kanta i Schopenhauera. Prema njoj se humorni učinak stvara iskustvom osjećaja neskladnosti ili nepodudarnosti između onoga što pretpostavljamo ili očekujemo da će biti slučaj i onoga što se zapravo događa u šali, vicu ili dosjetki (usp. Critchley 2002: 3). Na nju se nadovezuju suvremene kognitivne teorije humora (usp. Krikmann 2006). Inkongruentnost (nepodudarnost, proturječnost) (engl. incongruity) su mnogi teoretičari humora prepoznali kao njegovo ključno mjesto, ali u novije se vrijeme naglašava da humorna situacija ne proizlazi samo iz inkongruentnosti nego i iz njezina razrješenja (usp. Attardo 1994: 47-49; Oring 2003 1-13; Ritchie 2009; Oring 2016: 16-33; Prodanović Stankić 2016: 39-40; Marković 2019: 218-221). 
Uzimajući u obzir da su analizirani primjeri objavljeni na navedena dva profila na društvenim mrežama koji tom ciklusu humora daju širi kontekst, nadalje će se na odabranim primjerima pokušati pokazati kako se u njima ostvaruje humorni učinak. Načini razrješenja nepodudarnosti i stvaranja humornog učinka u slučaju vizualno-verbalnih humornih internetskih žanrova uglavnom su vezani i uz vizualni i uz verbalni dio primjera. $U$ većini slučajeva fotografska pozadina daje kontekst, a verbalna poruka inkongruentnu poentu, a ponekad postupak ide obrnutim slijedom (drugi primjer u slikovnom prilogu 14).

U manjem broju primjera za razrješenje nepodudarnosti nije ključan fotografski predložak u stvaranju poente jer je za njega dovoljna verbalna poruka, iako on pridonosi konačnom humornom učinku (usp. Dynel 2016: 680).

\section{When you ask a teacher how virtual learning is going so far.}

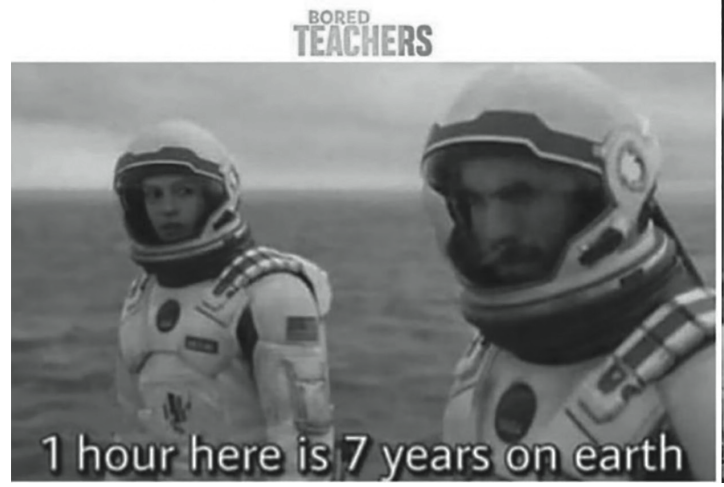

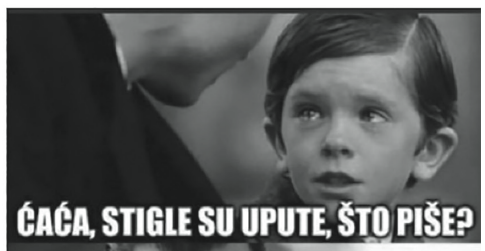

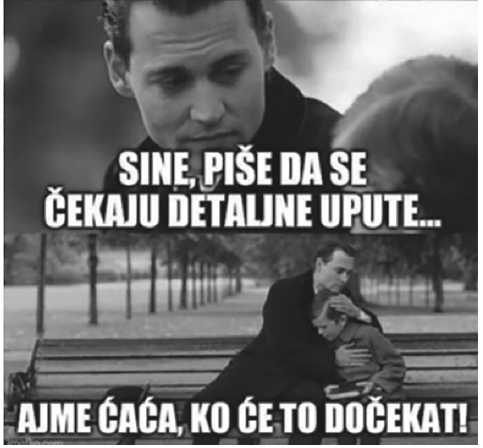

Slikovni prilog 15. Razrješenje inkongruentnosti u kombinaciji vizualnog i verbalnog. Izvor: Nastavnici.org

U većini se analiziranih primjera za postizanje humorne situacije koristi aluzija. Viralnim se fotografijama vizualno aludira na neku situaciju vezanu uz nastavni proces ili školski sustav koja s tekstom pridonosi stvaranju humornog sudara (vidi primjerice slikovne priloge $2 \mathrm{i}$ 3), a u image macro memima se na poznatom vizualnom predlošku koji nije vezan uz školski sustav verbalnim dijelom aludira na njega (vidi primjerice slikovni prilog 1). Česta je i stilska figura ironije u kojoj se humorni učinak postiže nepodudarnošću verbalnih poruka i vizualnog predloška, tj. verbalna je poruka suprotna od onoga što se njome kani kazati (Bagić 2012: 158). 

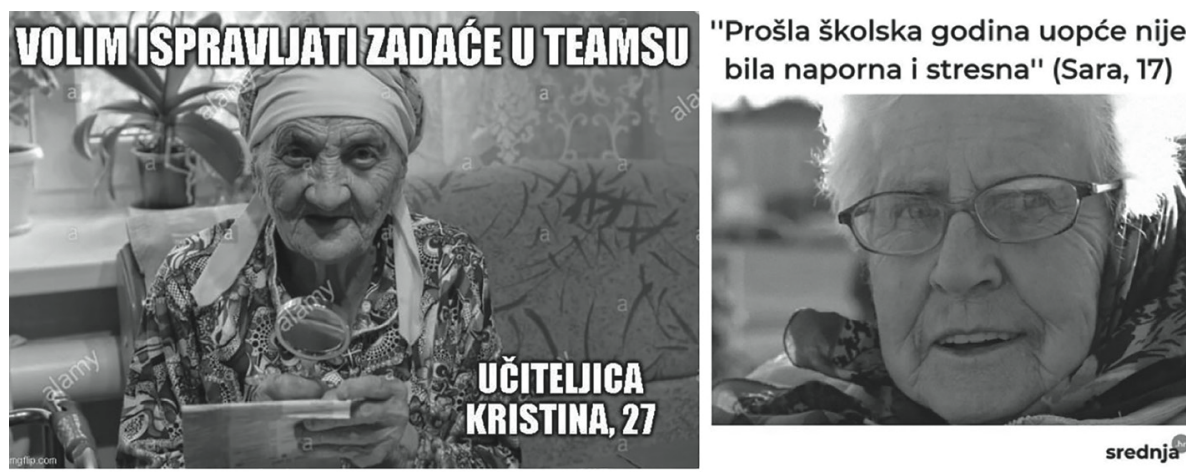
bila naporna i stresna" (Sara, 17)

Slikovni prilog 16. Prikaz ironičnih primjera. Izvor: Nastavnici.org i Srednja.hr

Verbalni dio poruke najčešće je direktno usmjeren na nastavni proces ili školski sustav, no zabilježeni su i primjeri u kojima se humorna situacija postiže postupkom intertekstualnosti (usp. Laineste i Voolaid 2016) gdje do razrješenja nepodudarnosti dolazi tako da se određeni poznati tekst uklopi u novonastalu situaciju, tj. aktualizira se $u$ novom kontekstu. Primjerice, poznata izjava hrvatskog branitelja Filipa Gaćine "Oba! Obadva su pala!" u ovom se slučaju odnosi na hakerski napad koji je na dan kada je trebala započeti nastava na mreži "srušio" Carnet te time otežao izvođenje nastave ${ }^{26}$ i na nefunkcioniranje aplikacije MS Teams, putem koje se izvodila nastava na mreži, zbog preopterećenosti sustava. Nadalje, poznata izjava Stjepana Radića "Ne srljajte kao guske u maglu” aktualizirana je verbalnom porukom "ostanite doma" koja je u vrijeme pandemije bila sveprisutna u medijima, a prati je i prigodni portret Stjepana Radića sa zaštitnom maskom na licu. Osim intertekstualnosti, zamijećeno je i parafraziranje naslova književnih djela (Waiting for Godot - Waiting for Like) ili vizualne intervencije poput uklapanja lika ministrice Divjak na fotografske predloške (vidi slikovni prilog 9).

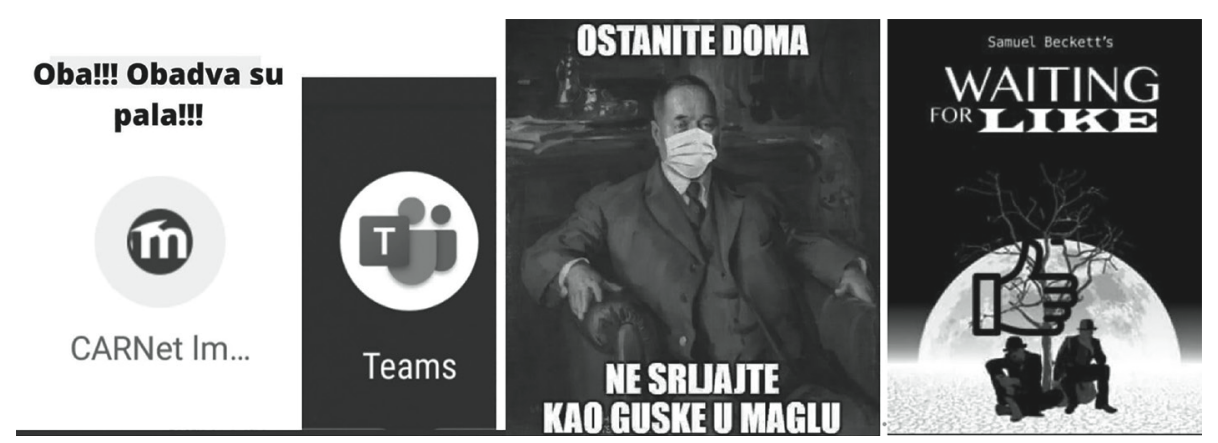

Slikovni prilog 17. Prikaz intertekstualnosti i parafraze. Izvor: Nastavnici.org

26 Vijest o hakerskom napadu na Carnet, https://www.index.hr/vijesti/clanak/hakeri-napali-carnetotezana-online-nastava/2165529.aspx?index_ref=read_more_d (pristup 9. 10. 2020.). 
U ovim se primjerima nalaze evocirani elementi tradicije i naslovi književnih djela koji su općepoznati, no primjenjuju se na posve neočekivano iskustvo, izaziva se kratki spoj, a time i humorni učinak (usp. Bagić 2012: 26, 234). Vizualno-verbalnim internetskim humornim žanrovima imanentne su i netočne konstrukcije rečenica ili namjerne gramatičke i pravopisne greške te uporaba lokalizama (usp. Dynel 2016: 662; Vásquez 2019: 29), kojima se recipijentu nastoji približiti govorna situacija. Njima se zamjenjuje realni govorni čin, ali i pridonosi humornom učinku (vidi slikovni prilog 1 i 13).

\section{ZAKLJUČNO}

Ovim se radom pokušalo ukazati na tematski uzak i specifičan ciklus vizualno-verbalnih internetskih žanrova koji se odnose na pandemiju koronavirusa u školskom sustavu. Upravo zbog njihove uske tematske povezanosti, ali i zbog toga što su aktualni dok je aktualna i tema koronavirusa u školstvu, povezani su s vicem o aktualnostima (engl. topical joke). Mogu se promatrati i u okviru newslorea jer na humorističan način komentiraju i kritiziraju vijesti koje su se pojavljivale u medijima, zatim u kontekstu političkog humora jer dio njih satirično prikazuje odluke čelnika i institucija u školstvu, ali i u kontekstu humora katastrofe jer na humorističan način prikazuju probleme uzrokovane pandemijom koronavirusa. Tematsko-motivskom analizom zaključeno je da su najčešće humoristično prikazivane novonastale situacije $\mathrm{u}$ izvođenju nastavnog procesa na daljinu, tj. izvođenje TV nastave i nastave na mreži (56\% primjera). Čestom su temom bili i prikazi novonastalih uvjeta u školskom sustavu koji su rezultat provođenja epidemioloških mjera u svrhu sprječavanja širenja virusa (24\% primjera). Istaknuta tema bila je i kritika ili komentiranje raznih smjernica i uputa koje je nastavno osoblje dobivalo od čelnih institucija ili osoba u obrazovanju (19\% primjera), a posebice onih tadašnje ministrice znanosti i obrazovanja Blaženke Divjak. Kao što je to imanentno vizualno-verbalnim humornim izričajima, humorni učinak se i u ovim primjerima najčešće postizao razrješenjem inkongruentnosti, gdje fotografska pozadina uglavnom daje kontekst, a verbalna poruka inkongruentnu poentu. Humornom učinku pridonose i stilske figure, od kojih je u ovim vizualno-verbalnim žanrovima najčešća aluzija, a uz nju se pojavljuju ironija i parafraza. Zamijećen je i postupak intertekstualnosti kojim se aktualiziraju određene općepoznate izreke u kontekstu pandemije koronavirusa. Naglašeno je da takav usko tematski orijentiran humor ponekad može biti nerazumljiv onima koji nisu dionici školskog sustava (vidi primjerice slikovni prilog 13), stoga je za njegovo razumijevanje nužan i širi kontekst koji se osigurava objavljivanjem na tematski usmjerenim profilima na društvenim mrežama. Viralnim se fotografijama uspješnije prikazala lokalna specifična situacija, a žanrom image macro globalna slika školstva u vrijeme pandemije. Zanimljivo je da je općenito u prikazu pandemije u školskom sustavu bio uspješniji žanr viralne fotografije negoli image macro internetski mem, koji je danas vjerojatno najrašireniji vizualno-verbalni internetski žanr. Pretpostavlja se da je razlog tomu specifičnost situacije koja je zornije prikazana viralnim fotografijama negoli internetskim 
memima, koji imaju unaprijed zadani fotografski predložak. Uloga humora u analiziranim internetskim zajednicama može se promatrati dvojako - s pozitivnim i negativnim učinkom. Humoristične situacije prikaza školskog sustava u vrijeme pandemije koronavirusa približavaju dionike nastavnoga procesa, tj. nastavnike na profilu Nastavnici.org i učenike na profilu Srednja.hr. Interakcija internetskih korisnika pri stvaranju, dijeljenju i komentiranju humornih internetskih žanrova utječe na formiranje kolektivnih identiteta unutar internetskih zajednica i stvara solidarnost među njima te im pomaže da zajednički prebrode koronakrizu. Što se pak tiče negativnih učinaka, internetski žanrovi prikazuju čelnike i institucije u obrazovanju uglavnom u negativnom svjetlu, no mogu se promatrati i kao upućena im konstruktivna kritika.

\section{LITERATURA I IZVORI}

Attardo, Salvatore. 1994. Linguistic Theories of Humor. Berlin, New York: Mouton de Gruyter.

Bagić, Krešimir. 2012. Rječnik stilskih figura. Zagreb: Školska knjiga.

Baran, Anneli. 2012. "Visual Humor on the Internet". U Estonia and Poland. Creativity and Tradition in Cultural Communication. Liisi Laineste, Dorota Brzozowska i Władysław Chłopicki, ur. Tartu: ELM Scholarly Press, 171-186.

Baym, Nancy K. 2004. "Izvedbe humora u računalno posredovanoj komunikaciji". U Etnografije interneta. Iva Pleše i Reana Senjković, ur. Zagreb: Institut za etnologiju i folkloristiku, 161-193.

Bebić, Domagoj i Marija Volarević. 2018. "Do Not Mess with a Meme. The Use of Viral Content in Communicating Politics". Communication \& Society 31/3: 43-56.

Bischetti, Luca, Paolo Canal i Valentina Bambini. 2020. "Funny but Aversive. A Large-scale Survey of the Emotional Response to Covid-19 Humor in the Italian Population during the Lockdown". Lingua. Dostupno na: https://www.sciencedirect.com/science/article/pii/S0024384120301716?via\%3Dihub\# (pristup 4. 11. 2020.). https://doi.org/10.1016/j.lingua.2020.102963

Blank, Trevor J. 2013. The Last Laugh. Folk Humor, Celebrity Culture, and Mass-Mediated Disasters in the Digital Age. Madison: The University of Wisconsin Press.

Cindrić, Marija. 2020. "Učenici će nositi maske, ali će moći sjediti s kolegama". 24 sata, 1. 9. Dostupno na: https://www.24sata.hr/tech/ucenici-ce-nositi-maske-ali-ce-moci-sjediti-s-kolegama-713908 (pristup 21. 9. 2020.).

Critchley, Simon. 2002. On Humor. London, New York: Routledge.

Davies, Christie. 2003. “Jokes that Follow Mass-Mediated Disasters in a Global Electronic Age". U Of Corpse. Death and Humor in Folklore and Popular Culture. Peter Narváez, ur. Logan: University Press of Colorado, 15-34. https://doi.org/10.2307/j.ctt46nsgh.5

Davison, Patrick. 2012. “The Language of Internet Memes”. U The Social Media Reader. Michael Mandiberg, ur. New York: New York University Press, 120-134.

de Seta, Gabriele. 2019. "Digital Folklore". U Second International Handbook of Internet Research. Jeremy Hunsinger, Matthew M. Allen i Lisbeth Klastrup, ur. Dordrecht: Springer, 1-17.

Dorst, John. 1990. "Tags and Burners, Cycles and Networks. Folklore in the Telectronic Age". Journal of Folklore Research 27/3: 179-190.

Dundes, Alan. 1987. “At Ease, Disease. AIDS Jokes as Sick Humor”. American Behavioral Scientist 30/3: 72-81. https://doi.org/10.1177/000276487030003006 
Dundes, Alan. 1989. "Six Inches from the Presidency. The Gary Hart Jokes as Public Opinion". Western Folklore 48/1: 43-51. https://doi.org/10.2307/1499980

Dynel, Marta, 2016. “I Has Seen Image Macros!' Advice Animals Memes as Visual-Verbal Jokes". International Journal of Communication 10/29: 660-688.

Ellis, Bill. 2001. "A Model for Collecting and Interpreting World Trade Center Disaster Jokes". New Directions in Folklore 5. Dostupno na: https://scholarworks.iu.edu/journals/index.php/ndif/article/ view/19881 (pristup 23. 9. 2020.).

Fiadotava, Anastasiya. 2020. "Sharing Humour Digitally in Family Communication". The European Journal of Humour Research 8/1: 95-111. https://doi.org/10.7592/EJHR2020.8.1.fiadotava

Frank, Russell. 2009. "The Forward as Folklore. Studying E-Mailed Humor". U Folklore and the Internet. Vernacular Expression in a Digital World. Trevor J. Blank, ur. Utah: Utah State University Press, 98-122. https://doi.org/10.2307/j.ctt4cgrx5.8

Frank, Russell. 2011. Newslore. Contemporary Folklore on the Internet. Jackson: University of Mississippi. https://doi.org/10.14325/mississippi/9781604739282.001.0001

Gal, Noam, Limor Shifman i Zohar Kampf. 2015. "It Gets Better'. Internet Memes and the Construction of Collective Identity". New Media \& Society 18/8: 1698-1714. https://doi. org/10.1177/1461444814568784

Highfield, Tim. 2015. "Tweeted Joke Lifespans and Appropriated Punch Lines. Practices Around Topical Humor on Social Media". International Journal of Communication 9: 2713-2734.

Jambrešić Kirin, Renata. 2017. “'Dance Kolinda Yes Kolinda Yes Kolinda Dance'. Humorous Representations of the Croatian President". Narodna umjetnost54/1: 7-27. https://doi.org/10.15176/vol54no101

Krikmann, Arvo. 2006. "Contemporary Linguistic Theories of Humour". Folklore. Electronic Journal of Folklore 33: 27-58. https://doi.org/10.7592/FEJF2006.33.kriku

Kršul, Dora. 2020. "Vlada mijenja Zakon o obrazovanju. Najmlađi učenici neće moći pasti razred, starijima dodatna šansa za popravak". Telegram, 28. 5. Dostupno na: https://www.telegram.hr/zivot/ vlada-mijenja-zakon-o-obrazovanju-najmladi-ucenici-nece-moci-pasti-razred-starijima-dodatna-sansa-za-popravak/ (pristup 17. 10. 2020.).

Kuipers, Giselinde. 2002. "Media Culture and Internet Disaster Jokes. Bin Laden and the Attack on the World Trade Center". European Journal of Cultural Studies 5: 451-471. https://doi. org/10.1177/1364942002005004296

Kuipers, Giselinde. 2005. “'Where Was King Kong When We Needed Him?' Public Discourse, Digital Disaster Jokes, and the Functions of Laughter after 9/11". The Journal of American Culture 28/1: 70-84. https://doi.org/10.1111/j.1542-734X.2005.00155.x

Laineste, Liisi. 2012. "Take it with a Grain of Salt. The Kernel of Truth in Topical Jokes". Folklore. Electronic Journal of Folklore 20-22: 7-25. https://doi.org/10.7592/FEJF2002.21.jokes

Laineste, Liisi. 2016. "From Joke Tales to Demotivators. A Diachronic Look at Humorous Discourse in Folklore". Traditiones 45/3: 7-25. https://doi.org/10.3986/Traditio2016450302

Laineste, Liisi i Piret Voolaid. 2016. "Laughing Across Borders. Intertextuality of Internet Memes". The European Journal of Humour Research 4/4: 26-49. https://doi.org/10.7592/EJHR2016.4.4.laineste

Marković, Ivan. 2018. “Jezikoslovci i vic. Slučaj Charlesa F. Hocketta”. U Humor u svakodnevnoj komunikaciji. Renata Jambrešić Kirin, Jelena Marković, Ljiljana Marks i Nataša Polgar, ur. Zagreb: Institut za etnologiju i folkloristiku, 133-161.

Marković, Ivan. 2019. Uvod u verbalni humor. Zagreb: Disput.

Marsh, Moira. 2019. "American Jokes, Pranks, and Humor". U The Oxford Handbook of American Folklore and Folklife Studies. Simon J. Bronner, ur. New York: Oxford University Press, 210-237. https:// doi.org/10.1093/oxfordhb/9780190840617.013.10 
McNeill, Lynne S. 2009. "The End of the Internet. A Folk Response to the Provision of Infinite Choice". U Folklore and the Internet. Vernacular Expression in a Digital World. Trevor J. Blank, ur. Utah: Utah State University Press, 80-97. https://doi.org/10.2307/j.ctt4cgrx5.7

Miltner, Kate M. 2014. “'There's no Place for lulz on LOLCats'. The Role of Genre, Gender, and Group Identity in the Interpretation and Enjoyment of an Internet meme". First Monday. Dostupno na: http://firstmonday.org/ojs/index.php/fm/article/view/5391/4103 (pristup 7. 10. 2020.). https://doi. org/10.5210/fm.v19i8.5391

Nastavnici.org. Dostupno na: https://www.facebook.com/groups/nastavnici.org (pristup 29. 9. 2020.).

Oring, Elliott. 1987. "Jokes and the Discourse on Disaster". The Journal of American Folklore 100/397: 276-286. https://doi.org/10.2307/540324

Oring, Elliott. 2003. Engaging Humor. Urbana, Chicago: University of Illinois.

Oring, Elliott. 2012. "Jokes on the Internet. Listing toward Lists". U Folk Culture in the Digital Age. The Emergent Dynamics of Human Interaction. Trevor J. Blank, ur. Utah: State University Press, 98-118. https://doi.org/10.7330/9780874218909.c05

Oring. Ellott. 2016. Joking Asides. The Theory, Analysis, and Aesthetics of Humor. Utah: University Press of Colorado. https://doi.org/10.7330/9781607324928

Predojević, Željko. 2019. “Mudrolije. Internetski memi poslovičnoga karaktera na primjeru mrežne stranice Mudrolije sa Twittera". Etnološka tribina 49/42: 152-172. https://doi.org/10.15378/18489540.2019.42.06

Predojević, Željko. 2021. "Humor katastrofe i internetski memi u vrijeme pandemije koronavirusa na primjeru dva instagramska profila". Anafora. Časopis za znanost o književnosti 8/1 [u tisku].

Prodanović Stankić, Diana. 2016. Verbalni humor u engleskom i srpskom jeziku. Novi Sad: Filozofski fakultet Novi Sad.

Ritchie, Graeme. 2009. "Variants of Incongruity Resolution”. Journal of Literary Theory 3/2: 313-332. https://doi.org/10.1515/JLT.2009.017

Ross, Andrew S. i Damian J. Rivers. 2017. "Digital Cultures of Political Participation. Internet Memes and the Discursive Delegitimization of the 2016 U.S. Presidential Candidates". Discourse, Context and Media 17: 1-11. https://doi.org/10.1016/j.dcm.2017.01.001

Shifman, Limor. 2014. Memes in Digital Culture. Cambridge, Massachusetts: The MIT Press. https://doi. org/10.7551/mitpress/9429.001.0001

Srednja.hr. Dostupno na: https://www.instagram.com/srednja_hr/ (pristup 29. 9. 2020.).

Suryawanshi, Shardul, Bharathi Raja Chakravarthi, Mihael Arcan i Paul Buitelaar. 2020. "Multimodal Meme Dataset (MultiOFF) for Identifying Offensive Content in Image and Text". TRAC@LREC (2020). https://www.aclweb.org/anthology/2020.trac-1.6/ (pristup 2. 11. 2020.).

Szerszunowicz, Joanna. 2018. "Typowy Janusz and Bad Luck Brian. On Meme Characters From A Cross-Linguistic And Cross-Cultural Perspective". The European Journal of Humour Research 6/2: 3-22. https://doi.org/10.7592/EJHR2018.6.2.230.szerszunowicz

Thelwall, Mike i Saheeda Thelwall. 2020. "Retweeting for COVID-19. Consensus Building, Information Sharing, Dissent, and Lockdown Life". Dostupno na: https://arxiv.org/abs/2004.02793 (pristup 3. 9. 2020.).

Tomašić, Josipa. 2018. “Humor u kuhinji. Što je smiješno u natpisima na zidnjacima”. U Humor u svakodnevnoj komunikaciji. Renata Jambrešić Kirin, Jelena Marković, Ljiljana Marks i Nataša Polgar, ur. Zagreb: Institut za etnologiju i folkloristiku, 61-80.

Užarević, Josip. 2012. Književni minimalizam. Zagreb: Disput.

Vargha, Katalin. 2018. "Creativity and Humor in the Online Folklore of the 2014 Elections in Hungary". Folklore. Electronic Journal of Folklore 74: 7-24. https://doi.org/10.7592/FEJF2018.74.vargha 
Vásquez, Camilla. 2019. Language, Creativity and Humour Online. London, New York: Routledge. https:// doi.org/10.4324/9781315159027

Vrbanus, Sandro. 2020. "Hrvatske škole pripremaju se na nastavu putem Interneta i televizije". BUG, 12. 3. Dostupno na: https://www.bug.hr/obrazovanje/hrvatske-skole-pripremaju-se-na-nastavu-putem-interneta-i-televizije-14189 (pristup 22. 9. 2020.).

Young, Dannagal G. 2018. "Theories and Effects of Political Humor. Discounting Cues, Gateways, and the Impact of Incongruities". U The Oxford Handbook of Political Communication. Kate Kenski i Kathleen Hall Jamieson, ur. Dostupno na: https://www.oxfordhandbooks.com/view/10.1093/ oxfordhb/9780199793471.001.0001/oxfordhb-9780199793471-e-29 (pristup 25. 10. 2020.).

Yus, Francisco. 2018. "Identity-related Issues in Meme Communication". Internet Pragmatics 1/1: 113133. https://doi.org/10.1075/ip.00006.yus

Yus, Francisco. 2020. "Incongruity-resolution Humorous Strategies in Image Macro Memes". Internet Pragmatics. Dostupno na: https://benjamins.com/catalog/ip.00058.yus (pristup 28. 10. 2020.).

\section{HUMOROUS PRESENTATION OF THE SCHOOL SYSTEM DURING THE CORONAVIRUS PANDEMIC ON THE EXAMPLE OF VISUAL-VERBAL INTERNET GENRES}

This article discusses humorous presentations of the school system during the coronavirus pandemic in visual-verbal internet genres (image macro memes and viral photos) in the context of topical humor. Internet genres are analyzed in relation to topical joke cycles. They are divided into three groups according to the most frequent topics: 1) the implementation of epidemiological measures to combat the spread of the coronavirus in schools, 2) the organization of the teaching process during the pandemic, and 3) the reaction of teaching staff to instructions and statements from educational leaders. The analysis reveals connections between the investigated examples and the news as well as satirical presentations of educational leaders. An attempt is made to analyze how humorous effects are achieved in these visual-verbal internet genres. The research focuses on examples posted on the social network profiles of two active web pages in the education system - Nastavnici.org and Srednja.hr - from the beginning of the pandemic in March until the end of September 2020.

Keywords: topical humor, netlore, topical jokes, image macros, viral photos, COVID-19, coronavirus, political humor, social networks, school system 